\title{
Anti-Inflammatory Activity of Hydroxydihydrocarvone
}

\author{
Damião P. de Sousa ${ }^{\mathrm{a}, *}$, Enilton A. Camargo ${ }^{\mathrm{a}}$, Fernando S. Oliveira ${ }^{\mathrm{b}}$, \\ and Reinaldo N. de Almeida ${ }^{\mathrm{b}}$ \\ a Departamento de Fisiologia, Universidade Federal de Sergipe, CEP 49100-000, Aracaju, \\ Sergipe, Brazil. Fax: +55 83321675 11. E-mail: damiao_desousa@yahoo.com.br \\ b Laboratório de Tecnologia Farmacêutica, Universidade Federal da Paraíba, \\ Caixa Postal 5009, CEP 58051-970, João Pessoa, Paraíba, Brazil \\ * Author for correspondence and reprint requests \\ Z. Naturforsch. 65c, 543-550 (2010); received March 30, 2010
}

Hydroxydihydrocarvone (HC) is a synthetic intermediate obtained by hydration of the natural compound $(R)-(-)$-carvone. The aim of the present study was to investigate the possible anti-inflammatory activity of orally administered HC. Toxicity, motor coordination, tail immersion test, as well as carrageenan-induced paw edema and myeloperoxidase (MPO) activity or peritonitis were all evaluated in rodents. $\mathrm{HC}$ was force-fed to the animals $1 \mathrm{~h}$ before the stimulus. The lethal dose $50 \%\left(\mathrm{LD}_{50}\right)$ of orally administered HC was $1259 \mathrm{mg} / \mathrm{kg}$. No changes in motor coordination were recorded in HC-treated mice in the rotarod test. The time of response to the thermoceptive stimulus in the tail immersion test was longer in HC-treated animals $(50,100$, and $200 \mathrm{mg} / \mathrm{kg})$ than in the vehicle-treated group. HC also significantly decreased the area under curve of carrageenan-induced rat paw edema at 100 and $200 \mathrm{mg} / \mathrm{kg}$ and MPO activity at $200 \mathrm{mg} / \mathrm{kg}$. Carrageenan-induced neutrophil recruitment to the peritoneal cavity was significantly reduced by $\mathrm{HC}$ at doses of $100 \mathrm{or} 200 \mathrm{mg} / \mathrm{kg}$, but not $50 \mathrm{mg} / \mathrm{kg}$. These findings demonstrate that orally administered HC exerts antinociceptive and anti-inflammatory activities in rats and mice.

Key words: Terpene, Essential Oils, Inflammation

\section{Introduction}

Medicinal plants represent an abounding source of compounds that have potential to treat a number of pathological conditions, such as inflammatory and/or painful conditions (Corson and Crews, 2007). Terpenoids are a large family of these compounds, found mainly in essential oils and have a range of applications, particularly in health. Plant-derived essential oils, have a variety of biological properties attributed to their chemical components, predominantly the monoterpenes (De Sousa et al., 2007a). Previous studies have shown that some monoterpenes present in many essential oils can exert antinociceptive (Abdel-Fattah et al., 2000; Gonçalves et al., 2008), anticonvulsant (De Sousa et al., 2007b, c), sedative (De Sousa et al., 2007d), and anti-inflammatory (Salminen et al., 2008) effects. Monoterpene derivatives also contain several pharmacological properties such as antinociceptive (Almeida et al., 1996; De Sousa et al., 2004) and antidepressant effects (De Sousa et al., 2006a), however, little information is available concerning their anti-inflammatory activity. It is worth mentioning that this class of compounds possesses an interesting therapeutic potential to treat inflammation, since many of them are shown to inhibit nuclear factor- $\kappa \mathrm{B}(\mathrm{NF}-\kappa \mathrm{B})$ signalling, a pleotropic pathway involved in the inflammatory and immune responses (Salminen et al., 2008).

Hydroxydihydrocarvone (HC, Fig. 1) is a synthetic intermediate prepared by hydration of the monoterpene $(R)-(-)$-carvone (Büchi and Wüest, 1979). This compound has functional groups and a structure similar to those of some monoterpenes that exert a depressant effect on the central nervous system (CNS) (Silva et al., 2007; Peana et al., 2003; Amaral et al., 2007). A previous study on the pharmacological activities of $\mathrm{HC}$ has reported its antinociceptive effect in formalin and<smiles>CC1=CCC(C(C)(C)O)CC1=O</smiles>

Fig. 1. Chemical structure of hydroxydihydrocarvone. 
hot-plate tests, following intraperitoneal (i.p.) administration to mice (Oliveira et al., 2008).

Based on the biological activity of terpenes from essential oils, we hypothetized that HC may have anti-inflammatory activity, along with the antinociceptive effect, following oral administration to mice or rats.

\section{Material and Methods}

\section{Chemical compound}

$\mathrm{HC}$ was prepared in our laboratory as previously described by Büchi and Wüest (1979). It was dissolved in 5\% Tween 80 and used as an emulsion.

\section{Animals}

Male Swiss mice $(25-35 \mathrm{~g})$ or male Wistar rats $(150-200 \mathrm{~g})$ were obtained from the Prof. Dr. Thomas George Laboratory of the Federal University of Paraíba or the Animal House of the Federal University of Sergipe, respectively. The animals were kept under standard environmental temperature conditions $\left[(21 \pm 1){ }^{\circ} \mathrm{C}\right]$ with $12 \mathrm{~h}$ light/dark periods, light beginning at 06:00 a.m.. Animals were maintained in fast for at least $6 \mathrm{~h}$, and water was provided ad libitum until $1 \mathrm{~h}$ prior to the experimental procedures. The animals were acclimatized to the laboratory for $1 \mathrm{~h}$ prior to the experiments. Animals received humane care in compliance with institutional guidelines.

\section{Determination of lethal dose $50 \%\left(L D_{50}\right)$}

$\mathrm{LD}_{50}$ was determined by giving different, orally administered doses of $\mathrm{HC}(500-2000 \mathrm{mg} / \mathrm{kg})$ to groups of mice $(n=10)$, thereafter mortality was recorded for $7 \mathrm{~d}$. The control group received only the vehicle. $\mathrm{LD}_{50}$ was determined by log-probit analysis.

\section{Rotarod test}

This technique has been previously described by Dunham and Miya (1957). Mice were placed on a rotating rod $(2.5 \mathrm{~cm}$ in diameter, rotating at $7 \mathrm{rpm}$ ) for a preselection test, and those able to remain on the rod for $3 \mathrm{~min}$ in three successive trials were selected for testing. $24 \mathrm{~h}$ after the preselection, four groups of mice were treated orally with $\mathrm{HC}(50,100$, and $200 \mathrm{mg} / \mathrm{kg})$ and vehicle. At 30, 60, 120, and $180 \mathrm{~min}$ after treatment, the animals were placed on a rotating bar of the rotarod apparatus for a maximum of $3 \mathrm{~min}$, and the time spent by each animal on the rotarod was recorded.

\section{Tail immersion test}

The lower two-thirds of the tail was immersed in a beaker containing water kept at $(50 \pm 0.5)$ ${ }^{\circ} \mathrm{C}$ (Janssen et al., 1963). The time in seconds until tail withdrawal from the water was considered as the reaction time. Mice that had a reaction time less than $4 \mathrm{~s}$ were selected. The reaction time was then measured 30,60, 120, and 180 min after i.p. administration of $\mathrm{HC}(50,100$, and $200 \mathrm{mg} / \mathrm{kg})$, vehicle (control) and morphine $(10 \mathrm{mg} / \mathrm{kg})$. The mice were exposed to hot water for no longer than $12 \mathrm{~s}$ to avoid tissue injury (Lira et al., 2002).

\section{Rat paw edema}

Wistar rats were orally pretreated with 50,100 , or $200 \mathrm{mg} / \mathrm{kg}$ of $\mathrm{HC}(5 \mathrm{~mL} / \mathrm{kg}$ ) or vehicle (Tween $80,5 \%)$. A positive control group of animals received dexamethasone $[2 \mathrm{mg} / \mathrm{kg}$, subcutaneous (s.c.)]. $1 \mathrm{~h}$ later, animals were anaesthetized by inhalation of halothane and received a subplantar injection of carrageenan $(0.5 \%)$ or sterile saline in the right paw in a final volume of $0.1 \mathrm{~mL}$. The paw volume was assessed immediately before carrageenan or saline injection, for the basal measurement, and 1,2, 3 and $4 \mathrm{~h}$ thereafter, using a hydroplethysmometer (model 7150, Ugo Basile, Comerio, Italy). The results are expressed as the increase in paw volume $(\mathrm{mL})$ calculated by subtracting the basal volume from each time point. The area under curve $\left(\mathrm{AUC}_{0-4 \mathrm{~h}}\right)$ was also calculated using the trapezoidal rule.

\section{Myeloperoxidase (MPO) activity in rat paw}

$4 \mathrm{~h}$ after injection of carrageenan or saline in rat paws, animals were sacrificed under halothane anaesthesia and posterior cervical dislocation. The tissues of the paws were immediately collected and placed in a test tube in the presence of $0.5 \%$ hexadecyltrimethylammonium bromide in $50 \mathrm{mmol} / \mathrm{L}$ potassium phosphate buffer, $\mathrm{pH}$ 6.0. Each tissue sample was homogenized, submitted to incubation at $60^{\circ} \mathrm{C}$ to inactivate catalase, and the homogenate was centrifuged at $12000 \times$ $g$ for $5 \mathrm{~min}$. The supernatants were collected and the MPO assay was performed using a microliter plate scanner. This consisted of mixing $20 \mu \mathrm{L}$ of sample with $200 \mu \mathrm{L}$ of $o$-dianisidine solution 
$(0.167 \mathrm{mg} / \mathrm{mL}$ of $o$-dianisidine dihydrochloride and $0.0005 \%$ hydrogen peroxide) before reading the plate. The changes in absorbance were measured at $460 \mathrm{~nm}$ every $15 \mathrm{~s}$ over a period of $5 \mathrm{~min}$. The MPO activity was expressed as MPO units (U MPO) per milligram of tissue. One unit of MPO activity degrades $1 \mu \mathrm{mol}$ of peroxide per minute at $25^{\circ} \mathrm{C}$ (Camargo et al., 2008).

\section{Leukocyte migration to peritoneal cavity}

Swiss mice (20-30 g) were orally pretreated with 50,100 , or $200 \mathrm{mg} / \mathrm{kg}$ of $\mathrm{HC}(5 \mathrm{~mL} / \mathrm{kg})$ or vehicle (Tween $80,5 \%$ ). $1 \mathrm{~h}$ later, animals were submitted to an injection of $0.25 \mathrm{~mL}$ of carrageenan $(1 \%)$ or sterile saline. Leukocyte counts were measured $4 \mathrm{~h}$ after carrageenan injection. The mice were sacrificed under halothane anaesthesia, and $2 \mathrm{~mL}$ of a phosphate-buffered saline (PBS) solution containing heparin $(5 \mathrm{UI} / \mathrm{mL})$ were injected into the peritoneal cavity. The abdomen was carefully massaged, and the fluid was withdrawn, placed in polypropylene centrifuge tubes, and centrifuged at $1000 \times g$ for $10 \mathrm{~min}$. The resulting cell pellet was gently resuspended in $1.0 \mathrm{~mL}$ of $\mathrm{PBS} /$ heparin solution, and the total and differential cell counts were assayed. Total cell counts were done using a Neubauer chamber while differential counts were carried out on a minimum of 200 cells using cytospin preparation stained with Diff-Quick. The cells were classified as polymorphonuclear (neutrophils and eosinophils) or mononuclear (macrophages, mast cells, and lymphocytes) based on normal morphological criteria.

\section{Statistical analysis}

The data obtained in the various experiments were evaluated using one-way analysis of variance (ANOVA) followed by Dunnett's multiple comparison test. The results obtained were considered significant when $P<0.05$.

\section{Results}

\section{Determination of lethal dose $50 \%$}

Orally administered $\mathrm{HC}$ was found to have an $\mathrm{LD}_{50}$ value of $1259 \mathrm{mg} / \mathrm{kg}$ with a confidence interval of $1000-1585 \mathrm{mg} / \mathrm{kg}$.

\section{Effect of HC on motor coordination}

At the doses evaluated in this study, $\mathrm{HC}$ had no significant effect on the motor coordination in the

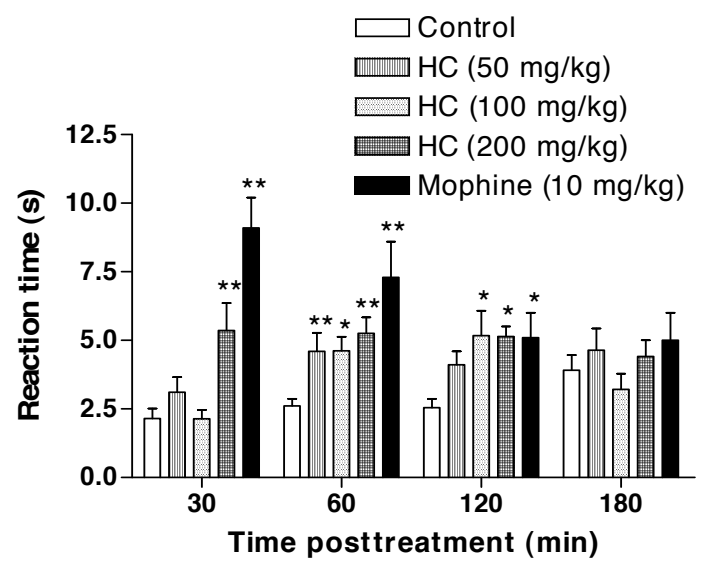

Fig. 2. Effect of HC treatment on the tail immersion test in mice. The values represent means \pm S.E.M. $(n=8)$; * $P<0.05$, ** $P<0.01$ significantly different from control.

rotarod test of treated animals at the time points used following treatment.

\section{Effect of HC on nociception in the tail immersion test}

Oral administration of $\mathrm{HC}$ at the doses of 50 , 100 , and $200 \mathrm{mg} / \mathrm{kg}$ led to a significant reduction in the nociceptive response to tail immersion in hot water, and this effect was dose-dependent (Fig. 2). This effect of $\mathrm{HC}$ was observed at the three evaluation time points $(30,60$, and $120 \mathrm{~min})$; however, the effect of $\mathrm{HC}$ was greater at $60 \mathrm{~min}$ post treatment. The decrease in time until tail withdrawal was similar to that achieved with $10 \mathrm{mg} / \mathrm{kg}$ of morphine.

\section{Effect of HC on rat paw edema and $M P O$ activity}

Carrageenan-induced rat paw inflammation characterized by the increase in paw volume peaked $3 \mathrm{~h}$ after injection $(n=6)$, when compared with the injection of saline $(n=5)$. Prior oral treatment of rats with $\mathrm{HC}$ the paw edema induced by carrageenan decreased dose-dependently as indicated in Fig. 3. The analysis of area under curves clearly showed the anti-inflammatory effect of $\mathrm{HC}$ in the rat paw edema model. HC significantly decreased the area under curve of carrageenan-injected rats $[(P<0.05$ for $50 \mathrm{mg} / \mathrm{kg}$ HC $(n=6)$ or $P<0.001$ for $100(n=6)$ or $200 \mathrm{mg} /$ $\mathrm{kg} \mathrm{HC}(n=6)$; Fig. 3B]. As expected, treatment with the glucocorticoid dexamethasone $(2 \mathrm{mg} / \mathrm{kg}$, 

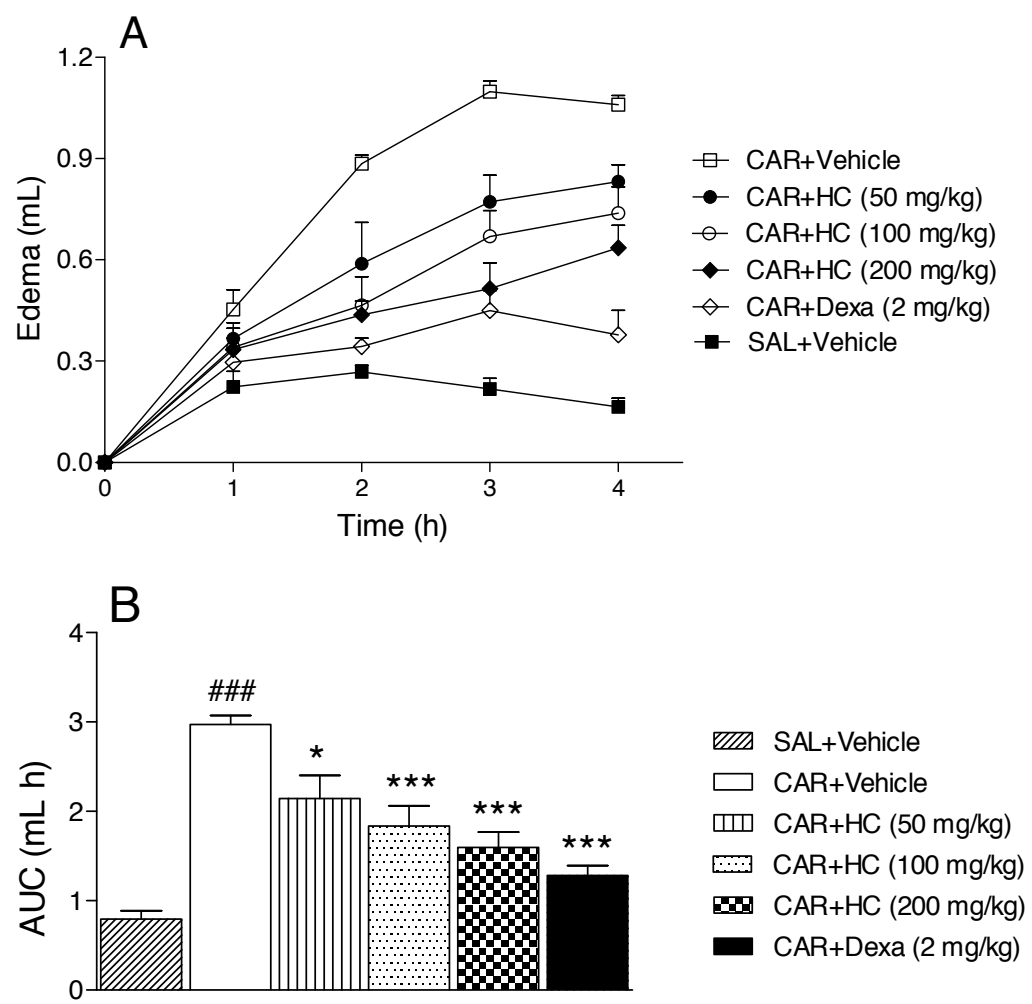

Fig. 3. Effect of HC treatment on carrageenan (CAR)-induced rat paw edema. (A) Time course of rat paw edema in animals injected with saline (SAL) or CAR and previously treated with vehicle, HC or dexamethasone (Dexa) at the indicated doses. (B) Resulting area under curve (AUC) of data from (A). Data are shown as means \pm S.E.M. of $n=5-7$ rats. ${ }^{\# \#} P<0.001$ compared with saline + vehicle group or $* P<0.05$ and $* * * P<0.001$ compared with carrageenan + vehicle group.

s.c., $n=5$ ) significantly inhibited the carrageenaninduced rat paw edema.

Four h after injection of carrageenan in rat paws we also found an increase $(P<0.001)$ in MPO activity, as a marker of neutrophil infiltration in paw tissue when compared with the salineinjected group, which exhibited very low MPO activity in paws $[(0.08 \pm 0.03) \mathrm{U} \mathrm{MPO} / \mathrm{mg}$ of paw tissue]. This effect was significantly inhibited by $\mathrm{HC}$ at $200 \mathrm{mg} / \mathrm{kg}(P<0.01, n=6)$, but not by the other doses of this compound. Dexamethasonetreated animals also showed a significant reduction of paw MPO activity $(P<0.01$; Fig. 4$)$.

\section{Effect of HC on leukocyte migration in} mice peritoneal cavity

As shown in Table I, the i.p. injection of carrageenan induced a marked leukocyte migration (mainly neutrophils) into the peritoneal cavity of mice ( $n=8, P<0.001)$, when compared with injection of saline $(n=5)$. Eosinophils were virtually absent in all groups analysed. Although the pretreatment with $\mathrm{HC}$ at 50,100 , or $200 \mathrm{mg} / \mathrm{kg}$ ( $n=6$ each) did not change the total leukocyte counts in the peritoneal cavity, it did significantly decrease the polymorphonuclear (neutrophil) cell counts at $100(P<0.001)$ or $200 \mathrm{mg} / \mathrm{kg}(P<0.05)$, which was not observed at $50 \mathrm{mg} / \mathrm{kg}$. As expected, mice treated with dexamethasone $(2 \mathrm{mg} / \mathrm{kg}$, s.c., $n=5$ ) showed a significant decrease in the total and polymorphonuclear counts. Mononuclear counts were affected neither by carrageenan injection nor by any doses of $\mathrm{HC}$ treatment.

\section{Discussion}

In the present study, the effect of orally administered $\mathrm{HC}$ was evaluated to investigate its effects on toxicity, motor behaviour/neurotoxicity, and 
Table I. Total and differential leukocyte counts in the peritoneal cavity of mice pretreated with vehicle, hydroxydihydrocarvone (HC) or dexamethasone (Dexa) and injected with saline or carrageenan.

\begin{tabular}{lccc}
\hline Group & \multicolumn{3}{c}{ Cells $\left(\cdot 10^{6} /\right.$ peritoneal cavity $)$} \\
\cline { 2 - 4 } & \multicolumn{1}{c}{ Total } & Mononuclear & Polymorphonuclear \\
\hline Saline + vehicle & $3.1 \pm 0.5$ & $3.0 \pm 0.5$ & $0.10 \pm 0.05$ \\
Carrageenan + vehicle & $11.8 \pm 0.7^{7 \# \#}$ & $3.4 \pm 0.4$ & $8.4 \pm 0.8^{\# \# \#}$ \\
Carrageenan + HC $(50 \mathrm{mg} / \mathrm{kg})$ & $10.9 \pm 1.5$ & $4.0 \pm 0.6$ & $6.9 \pm 1.5$ \\
Carrageenan + HC $(100 \mathrm{mg} / \mathrm{kg})$ & $9.1 \pm 0.9$ & $5.1 \pm 0.6$ & $4.0 \pm 0.5^{* * *}$ \\
Carrageenan + HC $(200 \mathrm{mg} / \mathrm{kg})$ & $9.7 \pm 0.7$ & $4.8 \pm 0.7$ & $4.9 \pm 0.6^{*}$ \\
Carrageenan + Dexa $(2 \mathrm{mg} / \mathrm{kg})$ & $5.0 \pm 1.1^{* * *}$ & $2.4 \pm 0.4$ & $2.6 \pm 0.6^{* * *}$ \\
\hline
\end{tabular}

Results are presented as means \pm S.E.M. of cells $\left(\cdot 10^{6} /\right.$ peritoneal cavity) for $n=5-8$ mice.

\#\#\# $P<0.001$ compared with saline + vehicle group or $* P<0.05$ and $* * * P<0.001$ compared with carrageenan + vehicle group.

antinociceptive action. Additionally, the effects of $\mathrm{HC}$ on standard models of inflammation induced by carrageenan were also investigated, and we have demonstrated that $\mathrm{HC}$ possesses a considerable anti-inflammatory activity in these models both in rats and mice.

Initially we determined the $\mathrm{LD}_{50}$ value of orally administrated $\mathrm{HC}$ and found that high doses of $\mathrm{HC}$ resulted in an $\mathrm{LD}_{50}$ of $1259 \mathrm{mg} / \mathrm{kg}$, which is higher than that found when the intraperitoneal route was used $(800 \mathrm{mg} / \mathrm{kg})$, indicating the lower toxicity of HC when administered orally (De

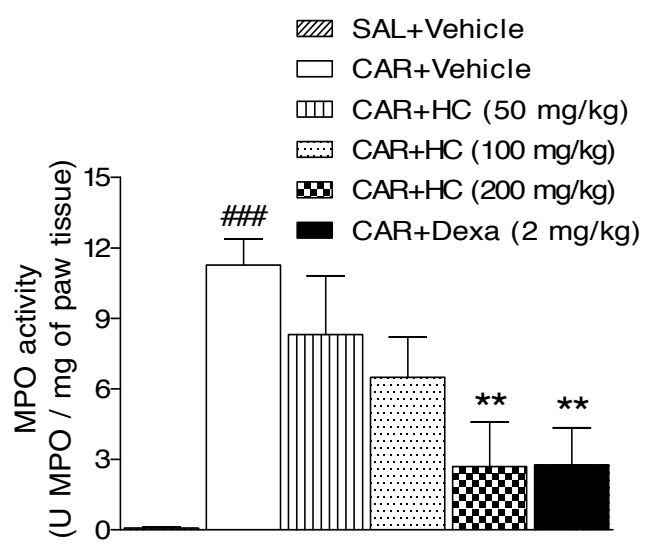

Fig. 4. Effect of HC treatment on carrageenan (CAR)induced neutrophil influx to rat paws. Myeloperoxidase (MPO) activity was assayed in rat paw from animals injected with saline (SAL) or CAR and previously treated with vehicle, HC or dexamethasone (Dexa) at the indicated doses. Data are shown as means \pm S.E.M. of $n=5-7$ rats. ${ }^{\# \#} P<0.001$ compared with saline + vehicle group or $* * P<0.01$ compared with carrageenan + vehicle group.
Sousa et al., 2006b). That may be due to either lower absorption or higher first-step metabolism. The highest dose used in the following tests was more than 6 times lower than the $\mathrm{LD}_{50}$ observed.

No changes were found in the motor coordination of HC-treated mice. The animals remained on the rotarod for more than $180 \mathrm{~s}$, suggesting that the inhibitory effect of $\mathrm{HC}$ may be achieved through central mechanisms and may not be the result of a blockade of the neuromuscular system (Perez et al., 1998; Amos et al., 2001). In the tail immersion test, in which a thermal stimulus is used, an increase in the reaction time is generally considered an important parameter of central antinociceptive activity (Rujjanawate et al., 2003). This test differentiates central opioid-like analgesics from peripheral analgesics (Asongalem et al., 2004). The tail flick response is believed to be a spinally mediated reflex (Chapman et al., 1985). Moreover, Grumbach (1966) has shown that the effectiveness of analgesic agents in the tail flick pain model is strongly correlated with the relief of human pain. In this test, the antinociceptive activity of $\mathrm{HC}$ was observed to be dose-dependent, presenting a central antinociceptive-like effect. This effect was observed up to $120 \mathrm{~min}$ post treatment as shown in the tail immersion test. This result showed that $\mathrm{HC}$ is also effective by the oral route and it is in agreement with data from studies carried out using the intraperitoneal route (De Sousa et al., 2006b).

Besides the antinociceptive effect of $\mathrm{HC}$, possible anti-inflammatory effects were also evaluated. Monoterpenes, as well as other terpenoids, are believed to exert anti-inflammatory activities, and this may take part in the inhibitory effects of many plant essential oils on experimental models 
of inflammation, as suggested for Salvia or Phlomis species (Kamatou et al., 2008; Limem-Ben et al., 2009). In this way, we hypothesized that HC, a synthetic monoterpene derivative, might have such activity, like the natural compounds extracted from plants. As expected, HC decreased the carrageenan-induced edema in rat paws in a dose-dependent manner, suggesting that HC may reduce the vascular permeability, thus decreasing the plasma leakage in rat paws. In addition, this compound reduced the carrageenan-induced neutrophil migration into rat paws, as expressed by the decrease of the MPO activity, a widely used biomarker of neutrophil content in tissues (Bradley et al., 1982; Camargo et al., 2008; Yshii et al., 2009). The latter result suggests that HC affects the neutrophil chemotaxis to the inflammatory focus, most probably through the inhibition of any chemoattractant mediator, as the cell recruitment induced by carrageenan involves production of many mediators, such as prostaglandin $\mathrm{E}_{2}$, nitric oxide, IL- $1 \beta$, and TNF- $\alpha$ (Salvemini et al., 1996; Loram et al., 2007). Of interest, the monoterpene carvacrol was recently shown to reduce the MPO activity in a model of periodontitis in rats (Botelho et al., 2008). In order to further investigate the negative modulation of $\mathrm{HC}$ on leukocyte chemotaxis, mice pretreated with $\mathrm{HC}$ were submitted to peritoneal injection of carrageenan. As shown previously by others (Salvemini et al., 1996; Alves et al., 2009), carrageenan injection increased the total leukocyte counts in the peritoneal cavity, which was mainly due to recruitment of neutrophils. Although HC treatment did not affect significantly the total or mononuclear (lymphocyte, monocyte, and macrophage) cell counts,

Abdel-Fattah A. M., Matsumoto K., and Watanabe H. (2000), Antinociceptive effects of Nigella sativa oil and its major component, thymoquinone, in mice. Eur. J. Pharmacol. 400, 89-97.

Almeida R. N., Hiruma C. A., and Barbosa-Filho J. M. (1996), Analgesic effect of rotundifolona in rodents. Fitoterapia 67, 334-338.

Alves C. F., Alves V. B., de Assis I. P., Clemente-Napimoga J. T., Uber-Bucek E., Dal-Secco D., Cunha F. Q., Rehder V. L., and Napimoga M. H. (2009), Antiinflammatory activity and possible mechanism of extract from Mikania laevigata in carrageenan-induced peritonitis. J. Pharm. Pharmacol. 61, 1097-1104.

Amaral J. F., Pequeno M. R., Neto M. R. A., Neto P. F. T., Moura B. A., Melo C. T. V., Araújo F. L. O., it decreased the neutrophil counts in the peritoneal cavity of mice. This is in agreement with the data showing reduced MPO activity in the paw of rats submitted to treatment with $\mathrm{HC}$, showing that this compound is active in both rats and mice.

The anti-inflammatory effects of $\mathrm{HC}$ might take place by various mechanisms, since terpenoids were demonstrated to exert inhibitory activity on the inflammatory signalling cascade of NF- $\kappa \mathrm{B}$ by different interactions in this pathway (Salminen et al., 2008). This is the case for the monoterpenes aucubin (Jeong et al., 2002), catalposide (Kim et al., 2004), genipin (Koo et al., 2004), $\alpha$-pinene (Zhou et al., 2004), and some other terpenoids, such as lupeol (Fernandez et al., 2001; Saleem, 2009) and ginkgolide B (Li et al., 2009). This mechanism could account for decreased expression of cyclo-oxygenase-2, inducible nitric oxide synthase, and inflammatory cytokine, along with other mediators and effects induced by translocation of NF- $\kappa \mathrm{B}$ to its DNA binding site (Karin and Greten, 2005; Perkins, 2007).

In summary, we have shown here that oral treatment with $\mathrm{HC}$ induces anti-inflammatory effects in rodents, characterized by the reduction of paw edema and neutrophil migration. Further studies are necessary to elucidate the mechanisms underlying the anti-inflammatory actions of this monoterpene.

\section{Acknowledgement}

The authors are grateful to José Crispim Duarte for the technical support and to the National Council of Technological and Scientific Development for providing financial support.

De Sousa D. P., Vasconcelos P. F., Vasconcelos S. M. M., and Sousa F. C. F. (2007), Antinociceptive effect of the monoterpene $R-(+)$-limonene in mice. Biol. Pharm. Bull. 30, 1217-1220.

Amos S., Adzu B., Binda L., Wambebe C., and Gamaniel K. (2001), Neuropharmacological effect of the aqueous extract of Sphaeranthus senegalensis in mice. J. Ethnopharmacol. 78, 33-37.

Asongalem E. A., Foyet H. S., Ekobo S., Dimo T., and Kamtchouing P. (2004), Antiinflammatory, lack of central analgesia and antipyretic properties of Acanthus montanus (Ness) T. Anderson. J. Ethnopharmacol. 95, 63-68.

Botelho M. A., Rao V. S., Montenegro D., Bandeira M. A., Fonseca S. G., Nogueira N. A., Ribeiro R. A., and 
Brito G. A. (2008), Effects of a herbal gel containing carvacrol and chalcones on alveolar bone resorption in rats on experimental periodontitis. Phytother. Res. 22, $442-449$.

Bradley P.P., Priebat D.A., Christensen R.D., and Rothstein G. (1982), Measurement of cutaneous inflammation: estimation of neutrophil content with an enzyme marker. J. Invest. Dermatol. 78, 206-209.

Büchi G. and Wüest H. J. (1979), New synthesis of betaagarofuran and of dihydroagarofuran. J. Org. Chem. 44, 546-549.

Camargo E. A., Ferreira T., Ribela M. T., de Nucci G., Landucci E. C., and Antunes E. (2008), Role of substance $\mathrm{P}$ and bradykinin in acute pancreatitis induced by secretory phospholipase $\mathrm{A}_{2}$. Pancreas 37, 50-55.

Chapman C. R., Casey K. L., Dubner R., Foley K. M., Gracely R. H., and Reading A. E. (1985), Pain measurement: an overview. Pain 22, 1-31.

Corson T. W. and Crews C. M. (2007), Molecular understanding and modern application of traditional medicines: triumphs and trials. Cell 130, 769-774.

De Sousa D. P., Raphael E., Brocksom U., and Brocksom T. J. (2004), Antinociceptive profile of 2-phenylselenyl-1,8-cineole in mice. Biol. Pharm. Bull. 27, 910-911.

De Sousa D. P., Schefer R. R., Brocksom U., and Brocksom T. J. (2006a), Synthesis and antidepressant evaluation of three para-benzoquinone mono-oximes and their oxy derivatives. Molecules 11, 148-155.

De Sousa D. P., Oliveira F. S., and Almeida R. N. (2006b), Evaluation of the central activity of hydroxydihydrocarvone. Biol. Pharm. Bull. 29, 811-812.

De Sousa D. P., Júnior E. V. M., Oliveira F. S., Almeida R. N., Nunes X. P., and Barbosa-Filho J. M. (2007a), Antinociceptive activity of structural analogues of rotundifolone: structure-activity relationship. Z . Naturforsch. 62 c, 39-42.

De Sousa D. P., Quintans-Júnior L. J., and Almeida R. N. (2007b), Evolution of the anticonvulsant activity of alpha-terpineol. Pharm. Biol. 45, 69-70.

De Sousa D. P., Nobrega F. F. F., and Almeida R. N. $(2007 \mathrm{c})$, Influence of the chirality of $(R)-(-)$ - and $(S)$ $(+)$-carvone in the central nervous system: A comparative study. Chirality 19, 264-268.

De Sousa D. P., Raphael E., Brocksom U., and Brocksom T. J. (2007d), Sedative effect of monoterpene alcohols in mice: a preliminary screening. Z. Naturforsch. 62 c, $563-566$.

Dunham M. W. and Miya T. S. (1957), A note on a simple apparatus for detecting neurological deficit in rat and mice. J. Am. Pharm. Assoc. Sci. 46, 208-209.

Fernandez M. A., de las Heras B., Garcia M. D., Saenz M. T., and Villar A. (2001), New insights into the mechanism of action of the anti-inflammatory triterpene lupeol. J. Pharm. Pharmacol. 53, 1533-1539.

Gonçalves J. C. R., Oliveira F. S., Benedito R. B., De Sousa D. P., Almeida R. N., and Araújo D. A. M. (2008), Antinociceptive activity of (-)-carvone: evidences of association with the peripheral nerve excitability decreasing. Biol. Pharm. Bull. 31, 1017-1020.

Grumbach L. (1966), The prediction of analgesic activity in man by animal testing. In: Pain (Knighton R. S. and Dumke P. R., eds.). Little Brown and Co., Boston, pp. 163-182.
Janssen P. A. J., Niemegeers C. J. E., and Dony J. G. H. (1963), The inhibitory effect of fentanyl and other morphine-like analgesics on the water induced tail withdrawal reflex in rats. Arzneim.-Forsch. 6, $502-507$.

Jeong H. J., Koo H. N., Na H. J., Kim M. S., Hong S. H., Eom J. W., Kim K. S., Shin T. Y., and Kim H. M. (2002), Inhibition of TNF-alpha and IL-6 production by aucubin through blockade of NF-kappaB activation RBL-2H3 mast cells. Cytokine 18, 252-259.

Kamatou G. P., Makunga N. P., Ramogola W. P., and Viljoen A. M. (2008), South African Salvia species: a review of biological activities and phytochemistry. J. Ethnopharmacol. 119, 664-672.

Karin M. and Greten F. R. (2005), NF-kappaB: linking inflammation and immunity to cancer development and progression. Nat. Rev. Immunol. 5, 749-759.

Kim S. W., Choi S. C., Choi E. Y., Kim K. S., Oh J. M., Lee H. J., Oh H. M., Kim S., Oh B. S., Kimm K. C., Lee M. H., Seo G. S., Kim T. H., Oh H. C., Woo W. H., Kim Y. S., Pae H. O., Park D. S., Chung H. T., and Jun C. D. (2004), Catalposide, a compound isolated from Catalpa ovata, attenuates induction of intestinal epithelial proinflammatory gene expression and reduces the severity of trinitrobenzene sulfonic acid-induced colitis in mice. Inflamm. Bowel. Dis. 10, $564-572$.

Koo H. J., Song Y. S., Kim H. J., Lee Y. H., Hong S. M., Kim S. J., Kim B. C., Jin C., Lim C. J., and Park E. H. (2004), Antiinflammatory effects of genipin, an active principle of Gardenia. Eur. J. Pharmacol. 495, 201-208.

Li R., Chen B., Wu W., Bao L., Li J., and Qi R. (2009), Ginkgolide B suppresses intercellular adhesion molecule-1 expression via blocking nuclear factorkappaB activation in human vascular endothelial cells stimulated by oxidized low-density lipoprotein. J. Pharmacol. Sci. 110, 362-369.

Limem-Ben A. I., Boubaker J., Ben S. M., Skandrani I., Bhouri W., Neffati A., Kilani S., Bouhlel I., Ghedira K., and Chekir-Ghedira L. (2009), Phytochemistry and biological activities of Phlomis species. J. Ethnopharmacol. 125, 183-202.

Lira S. R. S., Almeida R. N., Almeida F. R. C., Oliveira F. S., and Duarte J. C. (2002), Preliminary studies on the analgesic properties of the ethanol extract of Combretum leprosum. Pharm. Biol. 40, 213-215.

Loram L. C., Fuller A., Fick L. G., Cartmell T., Poole S., and Mitchell D. (2007), Cytokine profiles during carrageenan-induced inflammatory hyperalgesia in rat muscle and hind paw. J. Pain 8, 127-136.

Oliveira F. S., De Sousa D. P., and de Almeida R. N. (2008), Antinociceptive effect of hydroxydihydrocarvone. Biol. Pharm. Bull. 31, 588-591.

Peana A. T., D'Aquila P. S., Chessa M. L., Moretti M. D. L., Serra G., and Pippia P. (2003), (-)-Linalool produces antinociception in two experimental models of pain. Eur. J. Pharmacol. 460, 37-41.

Perez R. M. G., Perez J. A. L., Garcia L. M. D., and Sossa H. M. (1998), Neuropharmacological activity of Solanum nigrum fruit. J. Ethnopharmacol. 62, 43-48.

Perkins N. D. (2007), Integrating cell-signalling pathways with $\mathrm{NF}-\kappa \mathrm{B}$ and IKK function. Nat. Rev. Mol. Cell. Biol. 8, 49-62. 
Rujjanawate C., Kanjanapothi D., and Panthong A. (2003), Pharmacological effect and toxicity of alkaloids from Gelsemium elegans Benth. J. Ethnopharmacol. 89, 91-95.

Saleem M. (2009), Lupeol, a novel anti-inflammatory and anti-cancer dietary triterpene. Cancer Lett. 285, 109-115.

Salminen A., Lehtonen M., Suuronen T., Kaarniranta K., and Huuskonen J. (2008), Terpenoids: natural inhibitors of NF- $\kappa \mathrm{B}$ signaling with anti-inflammatory and anticancer potential. Cell. Mol. Life Sci. 65, 2979-2999.

Salvemini D., Wang Z. Q., Wyatt P. S., Bourdon D. M., Marino M. H., Manning P. T., and Currie M. G. (1996), Nitric oxide: a key mediator in the early and late phase of carrageenan-induced rat paw inflammation. Br. J. Pharmacol. 118, 829-838.
Silva M. I. G., Neto M. R. A., Neto P. F. T., Moura B. A., Amaral J. F., De Sousa D. P., Vasconcelos S. M. M., and De Sousa F. C. F. (2007), Central nervous system activity of acute administration of isopulegol. Pharmacol. Biochem. Behav. 88, 141-147.

Yshii L. M., Souza G. H., Camargo E. A., Eberlin M. N., Ribela M. T., Muscará M. N., Hyslop S., and Costa S. K. (2009), Characterization of the mechanisms underlying the inflammatory response to Polistes lanio lanio (paper wasp) venom in mouse dorsal skin. Toxicon 53, 42-52.

Zhou J. Y., Tang F. D., Mao G. G., and Bian R. L. (2004), Effect of $\alpha$-pinene on nuclear translocation of NF- $\kappa \mathrm{B}$ in THP-1 cells. Acta Pharmacol. Sin. 25, 480-484. 